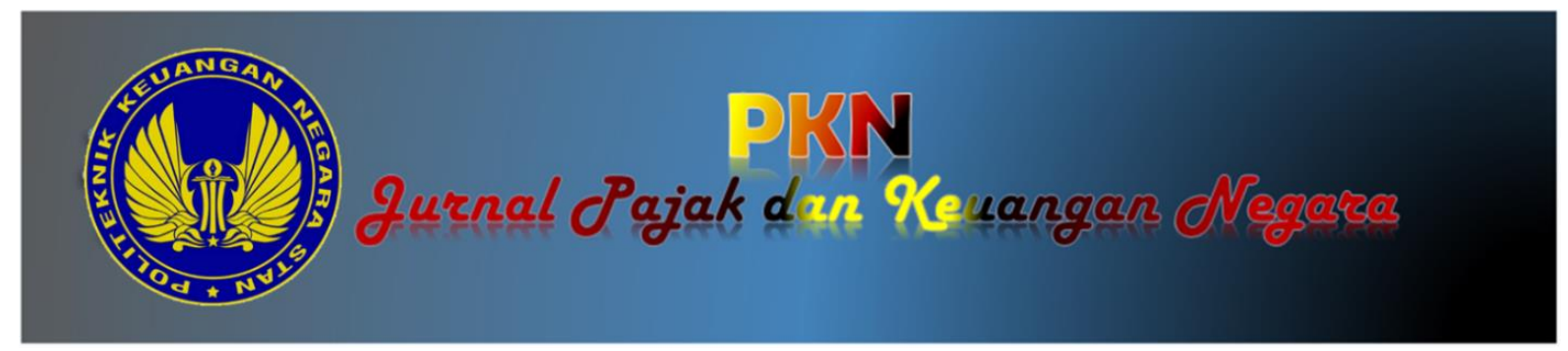

\title{
PENERIMAAN WAJIB PAJAK PADA AWAL IMPLEMENTASI E-FAKTUR PAJAK BERBASIS DESKTOP APPLICATION
}

\author{
Dhian Adhetiya Safitra \\ Politeknik Keuangan Negara STAN
}

Alamat Korespondensi: dhian.safitra@pknstan.ac.id

\section{INFORMASI ARTIKEL}

Diterima Pertama

[01 08 2021]

Dinyatakan Diterima

[24 08 2021]

KATA KUNCI:

Faktur pajak, Pajak pertambahan nilai, Theory of planned behaviour, technology acceptance models

\section{KLASIFIKASI JEL:}

Q580

\begin{abstract}
Currently, the tax authorities in Indonesia are actively shifting tax services to an online system. One of these tax services is e-Tax Invoice. The success of e-government projects such as e-Tax invoices depends not only on the reliability of ICT but also on taxpayers (PKP) as endusers. The purpose of this study is to identify the factors that influence the willingness of taxpayers to use online services with models based on the theory of planned behaviour (TPB) and technology acceptance models (TAM). We took one hundred samples from PKP registered at KPP Pratama Jakarta Pesanggrahan to achieve the research objectives and used Structural Equation Model to analyze the data. This study shows that only perceived easy-to-use variables that indirectly affect the behavioural intention of taxpayers to use. If KPP Pratama Jakarta Pesanggrahan wants to increase taxpayer incentives to use DGT's online applications/services, it is necessary to campaign for the ease of fulfilling tax obligations and the importance of paying taxes.
\end{abstract}

\section{ABSTRAK}

Saat ini otoritas pajak Indonesia giat mengalihkan pelayanan perpajakan ke sistem daring. Salah satu layanan perpajakan tersebut adalah e-Faktur Pajak. Keberhasilan implementasi e-Faktur Pajak tidak hanya bergantung pada keandalan TIK tetapi juga pada Pengusaha Kena Pajak (PKP) sebagai pengguna akhir. Tujuan dari penelitian ini adalah untuk mengidentifikasi faktor-faktor yang mempengaruhi kesediaan PKP untuk menggunakan layanan online merujuk the theory of planned behaviour (TPB) dan technology acceptance models (TAM). Kami mengambil seratus sampel dari PKP yang terdaftar di KPP Pratama Jakarta Pesanggrahan untuk mencapai tujuan penelitian dan menggunakan Structural Equation Model untuk menganalisis data. Penelitian ini menunjukkan bahwa hanya variabel perceived easy-touse yang secara tidak langsung mempengaruhi niat perilaku wajib pajak untuk menggunakan. Jika KPP Pratama Jakarta Pesanggrahan ingin meningkatkan insentif wajib pajak untuk menggunakan aplikasi/layanan daring DJP, maka perlu dilakukan upaya untuk mengampanyekan kemudahan pemenuhan kewajiban perpajakan dan pentingnya pembayaran pajak. 


\section{PENDAHULUAN}

E-Faktur Pajak merupakan salah satu batu pijakan implementasi layanan perpajakan berbasis internet di Indonesia setelah implementasi e-Filing dan e-Billing (Erdiansyah, 2021). Pelibatan Teknologi Informasi dan Komunikasi (TIK) pada pengelolaan administrasi Pajak Pertambahan Nilai (PPN) merupakan salah satu momentum dan inovasi untuk memastikan otoritas pajak dapat memantau seluruh transaksi Pengusaha Kena Pajak (PKP) secara cepat sebelum Surat Pemberitahuan Masa (SPM) PPN dilaporkan Wajib Pajak (WP) (Safitra, 2019b). Namun, keberhasilan proyek $e-$ government seperti e-Faktur Pajak tidak hanya bergantung pada keandalan TIK, namun juga bergantung pada masyarakat (dalam hal ini PKP) sebagai end user (Venkatesh, Sykes, \& Venkatraman, 2014).

Memahami pentingnya kanal elektronik pada suatu layanan, pemerintah di seluruh dunia secara cepat menggeser kanal konvensional ke kanal elektronik agar mendapatkan efektivitas dan efisiensi layanan (Lallmahomed, Lallmahomed, \& Lallmahomed, 2017). Dengan kanal elektronik, masyarakat dapat lebih mudah menjangkau layanan publik, menghemat waktu tempuh, hingga waktu antre (DeLone \& McLean, 2016). Kemudahan yang didapat masyarakat dalam kanal elektronik memberikan insentif bagi pemerintah untuk mengoptimalkan potensi kanal elektronik dengan mengembangkan layanan perpajakan (Bhuasiri, Zo, Lee, \& Ciganek, 2016) dengan harapan meningkatnya kepatuhan pajak baik formal maupun materiil. Makin menerima WP terhadap kanal layanan elektronik merupakan salah satu indikator keberhasilan implementasi suatu layanan.

Idealnya, kanal layanan dikembangkan berdasarkan preferensi pengguna. Penambahan kanal layanan atau pemenuhan kewajiban merupakan "keranjang belanja" yang dapat dipilih sesuai kenyamanan penggunanya. Jika memperhatikan penelitian Pieterson and Teerling (2008), penambahan kanal daring tidak mengurangi jumlah Wajib Pajak yang mengunjungi front desk di Belanda. Hal ini menjadi menaik karena adahal $80 \%$ dari Wajib Pajak di Belanda saat itu telah melaksanakan kewajiban perpajakan secara online. Jika melihat perkembangan layanan daring di Indonesia, terdapat beberapa perbedaan. E-Filing di awal implementasi merupakan opsi, namun secara bertahap diwajibkan untuk kelompok Wajib Pajak tertentu. Untuk e-Faktur Pajak tidak berlaku pilihan, walaupun dilakukan secara bertahap, namun penggunaannya bersifat wajib.
Jika memperhatikan penelitian terdahulu, para peneliti menggunakan theory planned behaviour (TPB) dan technology acceptance model (TAM) untuk mempelajari faktor-faktor yang mendorong seseorang menggunakan layanan elektronik atau daring yang diberikan pemerintah (Nabavi, Taghavi-Fard, Hanafizadeh, \& Taghva, 2016). Kebanyakan penelitian yang berhubungan dengan layanan perpajakan, lebih melihat dampak penggeseran layanan luring menjadi daring sebagai faktor yang meningkatkan kepatuhan pajak seperti Safitra and Djamaluddin (2020) yang membuktikan bahwa e-Faktur Pajak secara signifikan meningkatkan peluang untuk patuh WP PPN (atau PKP) sedangkan Tambun and Kopong (2017) dalam konteks e-filing, atau pemanfaatan e-government yang dapat menekan penghindaran pajak (Uyar, Nimer, Kuzey, Shahbaz, \& Schneider, 2021).

Penelitian ini akan menganalisis faktor-faktor yang mempengaruhi perilaku dan dorongan PKP dalam menggunakan aplikasi e-Faktur Pajak. Hal ini diperlukan sebagai landasan otoritas pajak untuk menentukan strategi peningkatan kepatuhan pajak. Jika merujuk pernyataan Devos (2013), kepatuhan pajak didorong faktor eksternal dan internal. Faktor eksternal merupakan strategi peningkatan kepatuhan yang dijalankan oleh otoritas pajak seperti pemberian sanksi, pengawasan, atau penegakan hukum. Sedangkan faktor internal adalah dorongan dari dalam diri PKP untuk patuh. Proksi dorongan dalam diri ini salah satunya adalah dorongan untuk patuh. Variabel-variabel yang ada pada TPB dan TAM dapat digunakan untuk menangkap persepsi PKP terhadap rigidity of compliance, salah satu variabel yang mempengaruhi secara negatif kepatuhan pajak (Devos, 2013, p. 23). Saat variabel-variabel yang mempengaruhi dorongan untuk menggunakan teridentifikasi, maka upaya yang dilakukan otoritas pajak akan tepat sasaran, mengingat sumber daya yang terbatas.

Dalam konteks layanan perpajakan daring Indonesia, penelitian menggunakan konsep TPA dan TPB didominasi dengan layanan e-Filing (Rahmat, 2020; Susanto, 2011; Tahar, Riaydh, Sofyani, \& Purnomo, 2020; Wiyono, 2008), e-billing (Nugroho, Susilowati, Ambarwati, \& Pratiwi, 2018; Yusup, Hardiyana, \& Sidharta, 2015), atau layanan terintegrasi djponline (Lestari, Suharto, Wirawan, \& Kurniawan, 2019; Maula, Rahim, \& Lannai, 2020; Prawati \& Britania, 2020). Hal ini bisa dimaklumi, karena implementasi e-Filing dan e-billing merupakan layanan daring perpajakan yang paling lama diterapkan di Indonesia. telah terdapat beberapa penelitian terhadap penerimaan e-Faktur Pajak seperti penelitian Perangin-angin, Respati, 
and Kusumawati (2018), Khairrunnisa and Yunanto (2018) atau Ariasih, Mahyuni, and Putra (2021), namun penelitan-penelitian tersebut hanya berfokus pada TAM. Perbedaan penelitian ini dengan penelitian terdahulu adalah mengelaborasi teori TAM dan TPB untuk melihat aspek perilaku yang mempengaruhi penerimaan PKP pada implementasi e-Faktur Pajak.

Tujuan penelitian ini adalah mengidentifikasi variabel-variabel yang mempengaruhi penerimaan PKP terhadap aplikasi e-Faktur Pajak. Dalam penelitian ini aplikasi dimaksud adalah aplikasi eFaktur Pajak berbasis desktop yang wajib digunakan oleh PKP pada awal implementasi e-Faktur Pajak. Perbedaan dengan penelitian terdahulu adalah masih belum banyak penelitian yang menguji penerimaan Wajib Pajak yang terdaftar pada administrasi PPN (PKP) terhadap penggunaan aplikasi e-Faktur Pajak, mengingat aplikasi ini digunakan secara wajib bukan sukarela dipilih oleh PKP.

\section{KERANGKA TEORI DAN PENGEMBANGAN HIPOTESIS}

\subsection{Theory of Planned behavior (TPB)}

Penelitian TPB mulai dikenal saat Fishbein and Ajzen (1977) menerbitkan hasil penelitiannya yang mengulas tentang theory of reason action (TRA) yang menjelaskan bahwa setiap orang memiliki kecenderungan sikap dalam merespon suatu perubahan. TRA didasarkan pada variabel yang fundamental, yaitu sikap dan norma subjektif. Sikap merepresentasikan repson positif atau negatif seseorang terhadap kinerja dari perilaku tertentu sedangkan norma adalah persepsi atas perilaku tertentu yang dipengaruhi oleh penilaian orang lain tanpa dirinya mengalami.

Niat berperilaku merupakan indikasi awal dari individu untuk melakukan suatu tindakan yang merupakan pengejawantahan persepsi. Ajzen (1985) memodifikasi TRA menjadi TPB dengan memasukkan teori perilaku. TPB melengkapi TRA dengan memasukkan unsur persepsi atas kontrol perilaku selain faktor perilaku individu dan norma subjektif. Pada awalnya TPB digunakan pada sektor swasta seperti melihat persepsi dan perilaku pada transaksi e-commerce (Hsu \& Chiu, 2004) namun berkembang dalam penggunaan layanan daring yang disediakan pemerintah (Hung, Chang, \& Yu, 2006).

\subsection{Technology Acceptance Model (TAM)}

Bagozzi and Yi (1988) menawarkan teori TAM untuk menjelaskan suatu model konseptual yang diterima dan diinginkan pengguna pada platform elektronik baru. Faktor yang mendasari penerimaan pengguna diwakili dengan variabel kegunaan yang dirasakan maupun kemudahan. Kegunaan digambarkan sebagai tingkat kepercayaan pengguna bahwa penggunaan platform elektronik tersebut meningkatkan produktivitas. Kemudahan digambarkan seberapa mudah pengguna beradaptasi dengan platform atau teknologi baru yang ada. TAM menggambarkan bawah terhadap hubungan positif antara persepsi kemudahan penggunaan dengan persepsi kegunaan. Kedua teori digunakan untuk membangun model hubungan antara faktor-faktor yang mempengaruhi keputusan untuk menggunakan suatu platform elektronik baru sebagaimana tergambar pada gambar 1. Platform baru dalam penelitian ini adalah e-Faktur Pajak. Dari teori yang ada ditarik beberapa hipotesis sebagaimana disajikan pada tabel 1.

Tabel 1 Hipotesis Penelitian

\begin{tabular}{|c|c|}
\hline $\begin{array}{l}\text { Hipotesis } \\
\text { Ke }\end{array}$ & $\mathrm{H}_{0}$ \\
\hline $\begin{array}{l}\text { Hipotesis } 1 \\
\text { RISK } \rightarrow \mathrm{BI}\end{array}$ & $\begin{array}{l}\text { Tidak terdapat pengaruh negatif antara } \\
\text { persepsi risiko dengan keinginan untuk } \\
\text { menggunakan }\end{array}$ \\
\hline $\begin{array}{l}\text { Hipotesis } 2 \\
\mathrm{PBC} \rightarrow \mathrm{BI}\end{array}$ & $\begin{array}{l}\text { Tidak terdapat pengaruh positif antara } \\
\text { persepsi kemampuan mengontrol } \\
\text { keinginan menggunakan }\end{array}$ \\
\hline $\begin{array}{l}\text { Hipotesis } 3 \\
\text { EXP } \rightarrow \text { BI }\end{array}$ & $\begin{array}{l}\text { Tidak terdapat pengaruh positif antara } \\
\text { pengalaman dengan keinginan }\end{array}$ \\
\hline $\begin{array}{l}\text { Hipotesis } 4 \\
\text { PU } \rightarrow \text { BI }\end{array}$ & $\begin{array}{l}\text { Tidak terdapat pengaruh positif antara } \\
\text { persepsi kemundahan penggunaan } \\
\text { dengan keinginan menggunakan }\end{array}$ \\
\hline $\begin{array}{l}\text { Hipotesis } 5 \\
\text { ATU } \rightarrow \mathrm{BI}\end{array}$ & $\begin{array}{l}\text { Tidak terdapat pengaruh positif antara } \\
\text { sikap terhadap penggunaan dengan } \\
\text { keinginan menggunakan }\end{array}$ \\
\hline $\begin{array}{l}\text { Hipotesis } 6 \\
\text { PU } \rightarrow \text { ATU }\end{array}$ & $\begin{array}{l}\text { Tidak terdapat pengaruh positif antara } \\
\text { persepsi pengguanaan dengan sikap } \\
\text { terhadap penggunaan }\end{array}$ \\
\hline $\begin{array}{l}\text { Hipotesis } 7 \\
\text { PE } \rightarrow \text { ATU }\end{array}$ & $\begin{array}{l}\text { Tidak terdapat pengaruh positif antara } \\
\text { persepsi kemundahan penggunaan } \\
\text { dengan sikap terhadap penggunaan }\end{array}$ \\
\hline $\begin{array}{l}\text { Hipotesis } 8 \\
\text { CPLX } \rightarrow \text { PU }\end{array}$ & $\begin{array}{l}\text { Tidak terdapat pengaruh negatif antara } \\
\text { kerumitan penggunaan dengan sikap } \\
\text { terhadap persepsi pengguanaan }\end{array}$ \\
\hline $\begin{array}{l}\text { Hipotesis } 9 \\
\text { EXP } \rightarrow \text { PU }\end{array}$ & $\begin{array}{l}\text { Tidak terdapat pengaruh positif antara } \\
\text { pengalaman dengan sikap terhadap } \\
\text { persepsi pengguanaan }\end{array}$ \\
\hline $\begin{array}{l}\text { Hipotesis } \\
10 \\
\text { PE } \rightarrow \text { PU }\end{array}$ & $\begin{array}{l}\text { Tidak terdapat pengaruh negatif antara } \\
\text { persepsi kemudahan dengan sikap } \\
\text { terhadap persepsi pengguanaan }\end{array}$ \\
\hline
\end{tabular}

Sumber: adaptasi Susanto (2011) 


\section{METODE PENELITIAN}

\subsection{Sumber dan Jenis Data}

Data yang dikumpulkan merupakan data primer yang diperoleh dengan mendia kuesioner. Kuesioner diberikan dengan dua media, pertama dengan google form yang disebarkan ke Pengusaha Kena Pajak melalui email dan/atau nomor yang terdaftar dalam platform WhatsApp dan yang kedua dengan kuesioner fisik (kertas) untuk Wajib Pajak yang datang ke Kantor Pelayanan Pajak Pesanggrahan pada tanggal 3 Juli s.d. 18 Agustus 2017. Pemilihan rentang waktu ini mempertimbangkan implementasi e-Faktur Pajak (berbasis aplikasi desktop) secara nasional pada Juli 2016. Kuesioner disusun dengan mengadopsi penelitian Susanto (2011) sebagaimana terlampir pada penelitian ini.

\subsection{Metode Analisis Data}

Mempertimbangkan konsep dari model yang dikembangkan yang digunakan untuk mengevaluasi efek langsung, tidak langsung, dan interaksi, penelitian ini menggunakan structural equation modelling (SEM). Metode analisis dengan SEM sangat lazim digunakan pada penelitian di bidang sosial dan bisnis, mengingat SEM memungkinkan untuk mengukur variabel laten dan/atau variabel psychometric (Hair, Page, \& Brunsveld, 2019)

\subsection{Model Penelitian}

Model penelitian yang digunakan dalam penelitian ini merupakan adaptasi dari penelitian Susanto (2011) yang meneliti tentang penggunaan e-Filing Pajak di Indonesia serta Lu and Ting (2013) yang meneliti tentang penggunaan Tax e-Filing di Taiwan. Model yang digunakan adalah tergambar pada gambar 1:

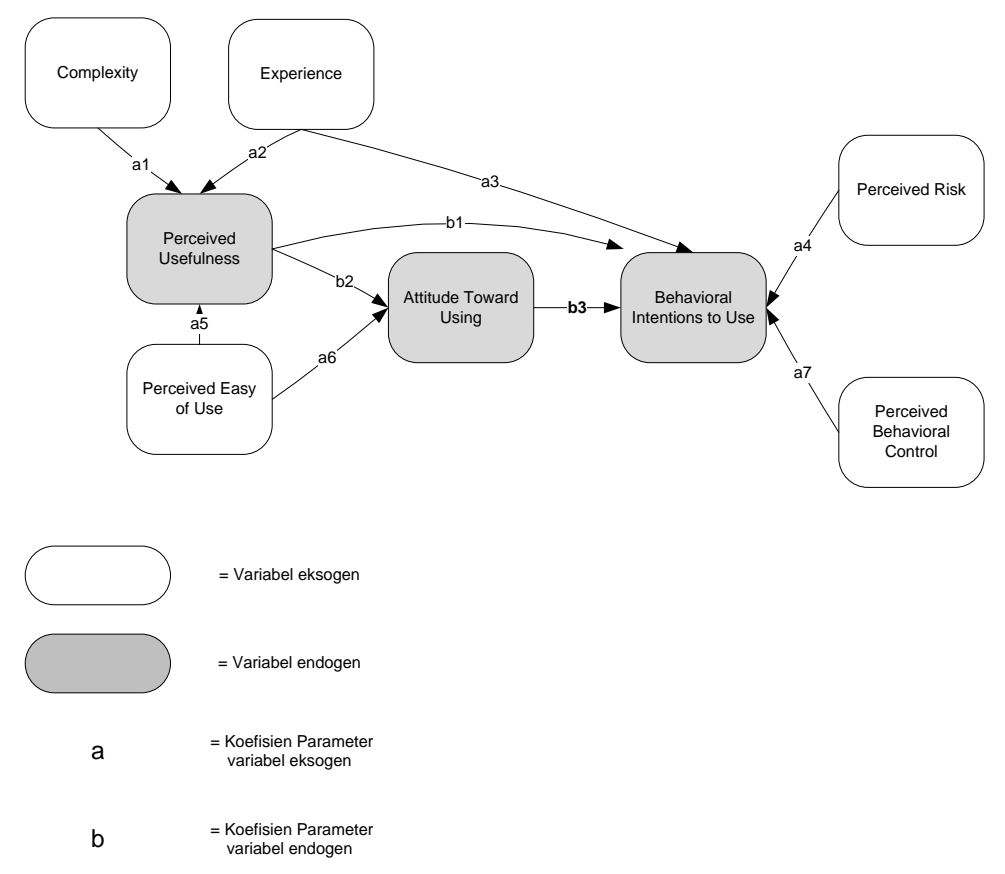

Gambar 1 Model Penelitian

Sumber: Penulis (2017) 


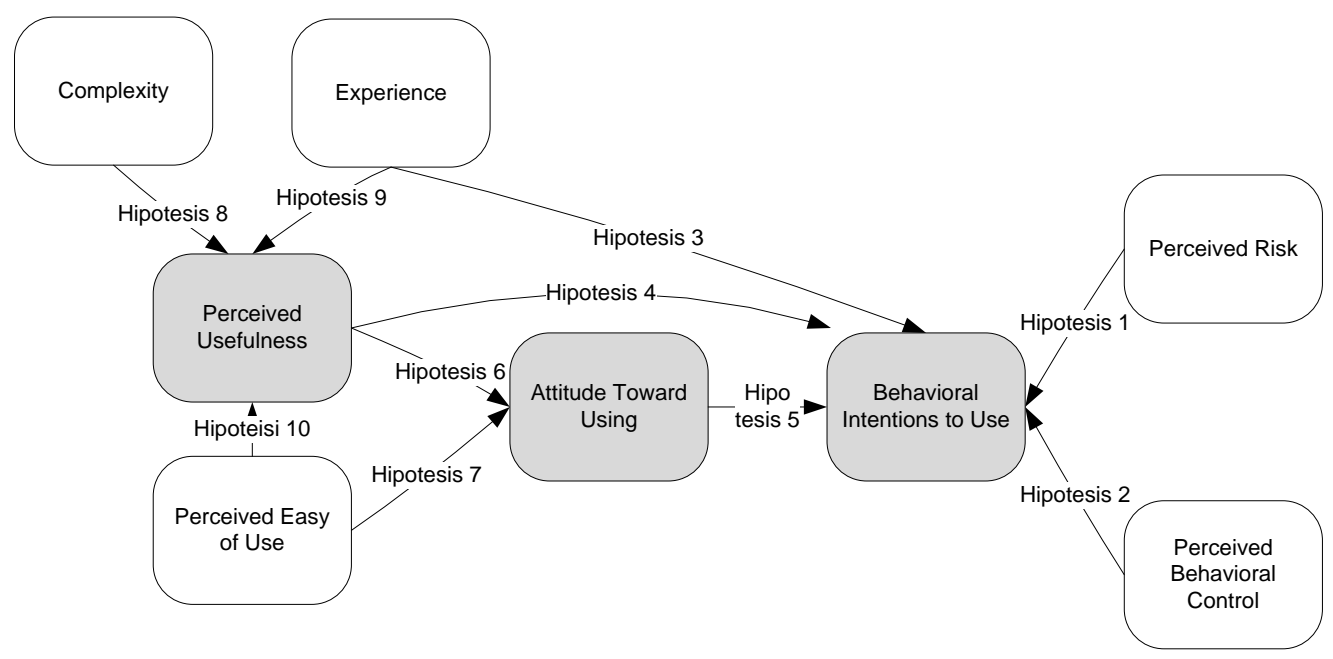

Gambar 2 Spesifikasi Model dan Hipotesis

Sumber: Penulis (2017)

\subsection{Spesifikasi Model}

Dari model di atas, dibuatlah first model yang akan diuji terlebih dahulu. Persamaan tersebut adalah:

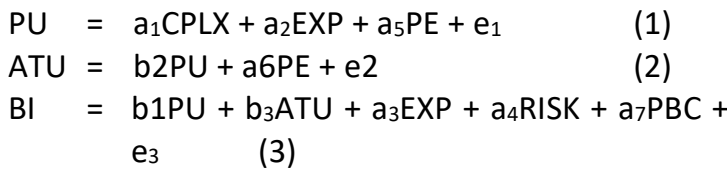

$B I=b 1 P U+b_{3} A T U+a_{3} E X P+a_{4} R I S K+a_{7} P B C+$ e 3 (3)

Dalam penelitian ini hubungan variabel laten dengan indikatornya bersifat reflektif sehubungan semua indikator merupakan gambaran dari variabel latennya. Variabel Laten atau konstruk dan indikatornya tercerminkan pada pertanyaanpertanyaan kuisioner yang ada pada Lampiran 1. Pertanyaan-pertanyaan kuisioner ini merupakan adaptasi dari penelitian Sutanto (2011) yang disesuaikan dengan objek penelitian, dalam hal ini aplikasi e-Faktur Pajak yang penggunaannya bukan merupakan pilihan, namun kewajiban bagi Pengusaha Kena Pajak. Berdasarkan gambar 2 ditarik beberapa hipotesis:

Tabel 2 Parameter Pengujian

\begin{tabular}{|c|c|c|}
\hline $\begin{array}{l}\text { Evaluasi } \\
\text { Model }\end{array}$ & Uji / Parameter & Nilai \\
\hline \multirow{3}{*}{$\begin{array}{l}\text { Model } \\
\text { Pengukuran }\end{array}$} & UJI VALIDITAS & Lebih dari 0.7 \\
\hline & Konvergen: Loading Factor & \\
\hline & $\begin{array}{l}\text { Diskriminan: } \\
\text { a. Average Variance Extracted (AVE) } \\
\text { b. Akar kuadrat AVE } \\
\text { c. Korelasi antar konstruk }\end{array}$ & $\begin{array}{l}\text { a. Lebih dari } 0.5 \\
\text { b. dan c. Akar AVE > Korelasi antar konstruk }\end{array}$ \\
\hline \multirow[t]{3}{*}{ - } & UJI RELIABILITAS & \\
\hline & Cronbach's Alpha & Lebih dari 0.6 \\
\hline & Composite Reability & Lebih dari 0.6 \\
\hline \multirow[t]{2}{*}{$\begin{array}{l}\text { Model } \\
\text { Struktural }\end{array}$} & Pengujian Hipotesis & \\
\hline & $\begin{array}{l}\text { a. Nilai t-statistik }>1.96 \text { tingkat keper } \\
\text { b. Nilai t-statistik }<1.96 \text { tingkat keper } \\
\text { c. Nilai t-statistik }>1.64 \text { tingkat keper } \\
\text { d. Nilai t-statistik }>1.64 \text { tingkat keper }\end{array}$ & $\begin{array}{l}\text { aan } 95 \% \text { Tolak } \mathrm{H}_{0} \text { dan hubungan signifikan } \\
\text { taan } 95 \% \text { Terima } \mathrm{H}_{0} \text { dan hubungan tidak signifikan } \\
\text { aan } 90 \% \text { Tolak } \mathrm{H}_{0} \text { dan hubungan signifikan } \\
\text { taan } 90 \% \text { Terima } \mathrm{H}_{0} \text { dan hubungan tidak signifikan }\end{array}$ \\
\hline
\end{tabular}




\subsection{Evaluasi Model}

Evaluasi model terdiri dari evaluasi model pengukuran (outer model) yang mengukur validitas konstruk (convergency dan discriminant validity) dan reabilitas (cronbach Alpha dan compisoye realicity). Parameter pengujiian dapat dilihat pada tabel berikut:

\section{HASIL PENELITIAN}

\subsection{Analisis Model (Goodnes of Fit)}

\subsubsection{First Model}

Variabel dipilih berdasarkan penelitian terdahulu dengan first model sebagaimana tergambar pada gambar 3 .

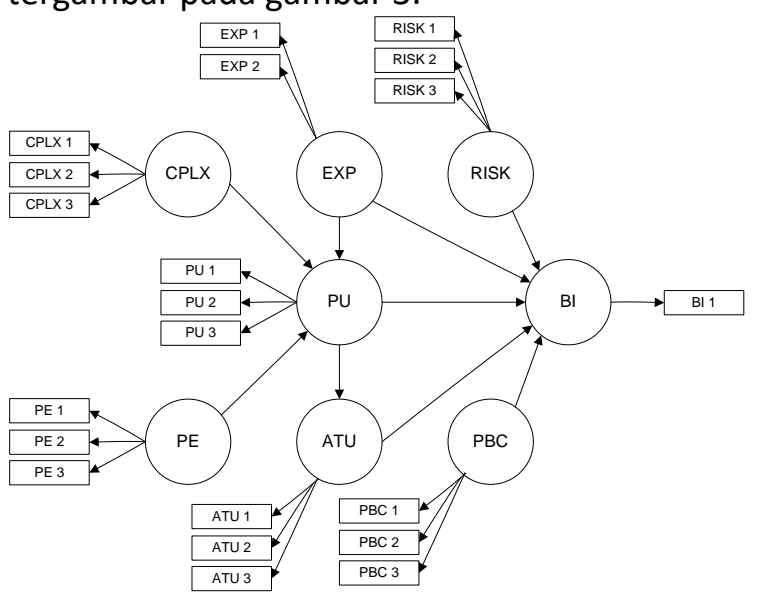

Gambar 3 First Model

Sumber: Penuis (2017) hasil olahan SmartPLS

Untuk memastikan model awal tersebut dapat digunakan untuk meninterpretasikan data, maka dilakukan beberapa uji sebagai berikut

\subsubsection{Measurement Model (GoF Outer Model)}

a. Convergent Validity

Indikator dikatakan valid secara konvergen jika nilai loading factor $\geq 0.5$. Untuk loading factor variabel PE (Percieved of easy to use) dapat dilihat pada Lampiran I. Nilai loading factor dari PE1 adalah 0.967, PE2 adalah 0960, dan PE3 adalah 0.723 mengindikasikan bahwa indikator PE1, PE2, dan PE3 valid. Secara lengkap nilai loading factor seluruh indikator dapat dilihat pada Tabel 3.

Tabel 3 Loading Factor

\begin{tabular}{ccc}
\hline \hline Indikator & $\begin{array}{c}\text { Loading } \\
\text { Factor }\end{array}$ & Validitas \\
\hline \hline CMPX1 & 0.954 & Valid \\
\hline CMPX2 & 0.975 & Valid \\
\hline PU1 & 0.998 & Valid \\
\hline PU2 & 0.908 & Valid
\end{tabular}

\begin{tabular}{ccc}
\hline \hline Indikator & $\begin{array}{c}\text { Loading } \\
\text { Factor }\end{array}$ & Validitas \\
\hline \hline PU3 & 0.864 & Valid \\
\hline PE1 & 0.967 & Valid \\
\hline PE2 & 0.960 & Valid \\
\hline PE3 & 0.723 & Valid \\
\hline EXP1 & 0.981 & Valid \\
\hline EXP2 & 0.955 & Valid \\
\hline ATU1 & 0.999 & Valid \\
\hline ATU2 & 0.859 & Valid \\
\hline ATU3 & 0.880 & Valid \\
\hline RISK1 & 0.969 & Valid \\
\hline RISK2 & 0.724 & Valid \\
\hline RISK3 & 0.964 & Valid \\
\hline BI1 & 1.000 & Valid \\
\hline PBC1 & 0.999 & Valid \\
\hline PBC2 & 0.847 & Valid \\
\hline PBC3 & 0.840 & Valid \\
\hline \hline
\end{tabular}

Sumber: Penuis (2017) hasil olahan SmartPLS

\section{b. Disciminant Validity Based on Average Variance Extracted (AVE)}

Uji selanjutnya meliHat nilai AVE. dimana $\lambda$ adalah loading factor, $\operatorname{Var}($ ei) adalah measurement error dimana Var (ei) $=1-\lambda 2$. Hasil output aplikasi SmartPLS menghasilkan angka berikut:

Tabel 4 Average Variance Extracted

\begin{tabular}{cll}
\hline No. & Variabel & AVE \\
\hline \hline 1 & ATU & 0.837 \\
\hline 2 & CPLX & 1.000 \\
\hline 3 & EXP & 0.931 \\
\hline 4 & PBC & 0.937 \\
\hline 5 & PE & 0.807 \\
\hline 6 & PU & 0.793 \\
\hline 7 & RISK & 0.856 \\
\hline
\end{tabular}

Sumber: Penuis (2017) hasil olahan SmartPLS

Indikator dikatakan valid secara discriminant jika nilai AVE-nya > 0.5. dari hasil di atas terlihat bahwa seluruh variabel valid. Uji validitas dianggap terpenuhi jika nilai akar kuadrat AVE lebih besar dari nilai korelais antar konstruk (Susanto, 2011). Hasil perhitunga manual adalah sebagai berikut:

Tabel 5 Akar Kuadrat AVE

\begin{tabular}{ccc}
\hline \hline Konstruk & AVE & Akar Kuadrat AVE \\
\hline \hline ATU & 0.837 & 0.915 \\
\hline BI & 1 & 1.000 \\
\hline
\end{tabular}




\begin{tabular}{ccc} 
CPLX & 0.931 & 0.965 \\
\hline EXP & 0.937 & 0.968 \\
\hline PBC & 0.807 & 0.898 \\
\hline PE & 0.793 & 0.891 \\
\hline PU & 0.856 & 0.925 \\
\hline RISK & 0.798 & 0.893 \\
\hline \hline \multicolumn{2}{l}{ Sumber: Penuis (2017) hasil olahan SmartPLS }
\end{tabular}

c. Uji t-value

Untuk memastikan semua indikator dapat digunakan, maka perlu dilihat t-value yang dihasilkan dari menu Bootsrap. Indikator dikatakan signifikan jika nilai t-valuenya $>1.96$. Dari tabel berikut disimpulkan bahwa seluruh variabel signifikan kecuali variabel BI1

Tabel 6 t-Value

\begin{tabular}{ccc}
\hline \hline Indikator & t-value & Signifikan \\
\hline \hline CMPX1 & 8.547 & Signifikan \\
\hline CMPX2 & 8.254 & Signifikan \\
\hline PU1 & 119.101 & Signifikan \\
\hline PU2 & 412.006 & Signifikan \\
\hline PU3 & 73.905 & Signifikan \\
\hline PE1 & 3.112 & Signifikan \\
\hline PE2 & 4.095 & Signifikan \\
\hline PE3 & 4.216 & Signifikan \\
\hline EXP1 & 31.868 & Signifikan \\
\hline EXP2 & 27.749 & Signifikan \\
\hline ATU1 & 95.514 & Signifikan \\
\hline ATU2 & 247.807 & Signifikan \\
\hline ATU3 & 76.745 & Signifikan \\
\hline RISK1 & 4.125 & Signifikan \\
\hline RISK2 & 4.944 & Signifikan \\
\hline RISK3 & 4.998 & Signifikan \\
\hline BI1 & 0.000 & Tidak Signifikan \\
\hline PBC1 & 7.132 & Signifikan \\
\hline PBC2 & 6.355 & Signifikan \\
\hline PBC3 & 6.976 & Signifikan \\
\hline
\end{tabular}

Sumber: Penuis (2017) hasil olahan SmartPLS

Dari beberapa uji model awal/first model diperoleh hasil sebagai berikut:

Tabel 7 Hasil Uji Fist Model

\begin{tabular}{cccc}
\hline \hline Indikator & C. Val & Disc Val. & Sign \\
\hline \hline CMPX1 & Valid & Valid & Signifikan \\
\hline CMPX2 & Valid & Valid & Signifikan \\
\hline PU1 & Valid & Valid & Signifikan \\
\hline PU2 & Valid & Valid & Signifikan \\
\hline PU3 & Valid & Valid & Signifikan \\
\hline PE1 & Valid & Valid & Signifikan \\
\hline PE2 & Valid & Valid & Signifikan \\
\hline
\end{tabular}

\begin{tabular}{cccc}
\hline \hline Indikator & C. Val & Disc Val. & Sign \\
\hline \hline PE3 & Valid & Valid & Signifikan \\
\hline EXP1 & Valid & Valid & Signifikan \\
\hline EXP2 & Valid & Valid & Signifikan \\
\hline ATU1 & Valid & Valid & Signifikan \\
\hline ATU2 & Valid & Valid & Signifikan \\
\hline ATU3 & Valid & Valid & Signifikan \\
\hline RISK1 & Valid & Valid & Signifikan \\
\hline RISK2 & Valid & Valid & Signifikan \\
\hline RISK3 & Valid & Valid & Signifikan \\
\hline BI1 & Valid & Valid & Tidak \\
& & & Signifikan \\
\hline PBC1 & Valid & Valid & Signifikan \\
\hline PBC2 & Valid & Valid & Signifikan \\
\hline PBC3 & Valid & Valid & Signifikan \\
\hline \hline
\end{tabular}

Sumber: Penuis (2017) hasil olahan SmartPLS

Semua indikator dapat digunakan kecuali indikator BI1 yang tidak signifikan saat dilakukan uji t-value. Namun, mempertimbangkan indikator tersebut dinyatakan valid oleh uji convergent validity dan discriminant validity maka indikator tersebut dipertahankan. Implikasinya adalah first model dilanjutkan ke tahap berikutnya.

4.1.3. Structural Model (GoF Inner Model)

a. Uji Reabilitas

Uji Reabilitas yang dipakai adalah dengan melihat nilai Cronbachs Alpha dan Composite Reliability yang nilainya harus di atas 0.6 (Susanto. 2011). Hasil yang diperoleh pada aplikasi SmartPLS disajikan pada tabel 8. Dapat dilihat bawa nilai Cronbach's Alpha dan Composite Reliability dari semua konstruk di atas 0.6 yang mengisyaratkan semua konstruk reliabel.

Tabel 8 Cronbach's Alpha

\begin{tabular}{lll}
\hline No. & Variabel & $\begin{array}{c}\text { Coronbach's } \\
\text { Alpha }\end{array}$ \\
\hline \hline 1 & ATU & 0.901 \\
\hline 2 & CPLX & 0.927 \\
\hline 3 & EXP & 0.936 \\
\hline 4 & PBC & 0.867 \\
\hline 5 & PE & 0.897 \\
\hline 6 & PU & 0.915 \\
\hline 7 & RISK & 0.901 \\
\hline
\end{tabular}

Sumber: Penuis (2017)

b. Hasil Pengujian Hipotesis

Pada GoF inner model ini akan dilakukan tahap yang dapat memberikan kepastian bahwa semua pengaruh antar variabel adalah signifikan. jika ditemui pengaruh variabel satu ke variabel lainnya tidak signifikan, maka garis pengaruh tersebut harus di singkirkan. Untuk menguji 
signifikansi pengaruh, maka akan dilihat nilai tvalue yang akan dibandingkan dengan z-score. Jika t-value > z-score maka variabel tersebut signifikan.

Tabel 9 Kesimpulan Hipotesis

\begin{tabular}{lcc}
\hline \multicolumn{1}{c}{ Hipotesis Ke } & T Statistik & Path Coev \\
\hline $\begin{array}{l}\text { Hipotesis 1 } \\
\text { RISK } \rightarrow \text { BI }\end{array}$ & 0.451 & 0.060 \\
\hline $\begin{array}{l}\text { Hipotesis 2 } \\
\text { PBC } \rightarrow \text { BI }\end{array}$ & 0.877 & -0.109 \\
\hline $\begin{array}{l}\text { Hipotesis 3 } \\
\text { EXP } \rightarrow \text { BI }\end{array}$ & 0.865 & 0.090 \\
\hline $\begin{array}{l}\text { Hipotesis 4 } \\
\text { PU } \rightarrow \text { BI }\end{array}$ & 0.656 & -0.072 \\
\hline $\begin{array}{l}\text { Hipotesis 5 } \\
\text { ATU } \rightarrow \text { BI }\end{array}$ & 0.614 & 0.067 \\
\hline $\begin{array}{l}\text { Hipotesis 6 } \\
\text { PU } \rightarrow \text { ATU }\end{array}$ & 0.231 & 0.026 \\
\hline $\begin{array}{l}\text { Hipotesis 7 } \\
\text { PE } \rightarrow \text { ATU }\end{array}$ & 1.731 & $0.210 *$ \\
\hline $\begin{array}{l}\text { Hipotesis 8 } \\
\text { CPLX } \rightarrow \text { PU }\end{array}$ & 1.393 & 0.144 \\
\hline $\begin{array}{l}\text { Hipotesis 9 } \\
\text { EXP } \rightarrow \text { PU }\end{array}$ & 0.843 & 0.102 \\
\hline $\begin{array}{l}\text { Hipotesis 10 } \\
\text { PE } \rightarrow \text { PU }\end{array}$ & 0.293 & -0.035 \\
\hline \hline
\end{tabular}

Catatan: t-tabel sig $90 \%=1.665$ dan t-tabel sig $95 \%=1.992$

Dari hasil pengujian tersebut tergambarkan konstruk yang memiliki pengaruh dan yang tidak memiliki pengaruh. Secara skema, hubungan antar konstruk yang memiliki hubungan dan berpengaruh signifikan adalah PU dan ATU.

\section{c. Analisis Jalur}

Analisis jalur (path) memetakan variabel endogen yang dopengaruhi variabel eksogen dengan melihat koefisien korelasi. Pada penelitian ini, hanya ditemukan 1 path, dimana yang di analisa adalah faktor PU yang mempengaruhi variabel Attitude Toward Using yang menghasilkan persamaan berikut:

ATU = 0,26 PU + e4

Persamaan lain tidak disertakan karena dari hasil pengujian variabel lainnya tidak signifikan mempengaruhi variabel endogennya. Anilisis terhadap path di atas adalah di mana sikap terhadap penggunaan aplikasi e-Faktur Pajak (Attitude Towar Using) dipengaruhi secara langsung (direct effect) oleh persepsi kegunaan (Perceived usefulness) dimana pengusaha kena pajak memberikan respon positif terhadap aplikasi eFaktur Pajak. nilai 0.026 menunjukkan pengaruh yang sangat kecil terhadap sikap penggunaa (Attitude Toward Using).

Variabel-variabel yang digunakan pada penelitian ini terbukti tidak saling mempengaruhi secara signifikan sehingga dapat disimpulkan bahwa PKP tidak menerima adanya aplikasi e-
Faktur Pajak jika tidak diwajibkan penggunaannya dan tidak ada variabel yang mendorong mereka menggunakan aplikasi e-Faktur, Ini bisa terjadi diduga karena objek penelitian ini dengan penelitian Susanto (2011) yang menjadi rujukan memiliki karakter yang berbeda. Dampaknya adalah model penelitian yang dipergunakan untuk meneliti e-Filing tidak ideal digunakan pada eFaktur Pajak. perbedaan mendasar antara implementasi e-Faktur Pajak dan e-Filing adalah, aplikasi e-Faktur Pajak secara mandatori diwajibkan bagi seluruh Wajib Pajak yang terdaftar sebagai Pengusaha Kena Pajak, sedangkan e-Filing adalah layanan yang diberikan ke Wajib Pajak sebagai salah satu alternatif kemudahan dalam pelaporan pajak.

Hasil penelitian ini tidak mendukung penelitian terdahulu yang meneliti tentang e-Filing (Rahmat, 2020; Susanto, 2011; Tahar et al., 2020; Wiyono, 2008), e-billing (Nugroho et al., 2018; Yusup et al., 2015), atau DJP Online (Lestari et al., 2019; Maula et al., 2020; Prawati \& Britania, 2020), dimana variabel-variabel yang ada pada TPB dan TAM merupakan variabel pendorong bagi pengguna layanan untuk menggunakan layanan daring tersebut.

\subsection{Koefisien Determinasi}

Koefisien Determinasi ditunjukkan dengan nilai R-Square untuk menjelaskan variasi pada variabel dependen. Nilai R-Square dari aplikasi SmartPLS dapat dilihat pada tabel di bawah ini:

Tabel 10: R-Square

\begin{tabular}{llcc}
\hline No. & Variabel & $\mathrm{R}^{2}$ & $\mathrm{R}^{2} \mathrm{Adj}$ \\
\hline \hline 1 & ATU & 0.044 & 0.025 \\
\hline 2 & $\mathrm{BI}$ & 0.023 & -0.029 \\
\hline 3 & PO & 0.035 & 0.004 \\
\hline
\end{tabular}

Sumber: Penuis (2017) hasil olahan SmartPLS

Dari nilai R-square tersebut dapat disimpulkan bahwa, variabel-variabel independen yang ada pada penelitian ini hanya menjelaskan variabel dependen tidak lebih dari $5 \%$ yang mana sisanya dijelaskan oleh faktor lain. Dari hasil yang diperoleh, ada beberapa kemungkinan yang menyebabkan model yang disusun berdasarkan teori yang ada tidak dapat menjelaskan hubungan antar variabelnya secara signifikan, kemungkinan tersebut seperti objek penelitian dalam hal ini aplikasi e-Faktur Pajak ini berbeda karakter dengan layanan e-Filing, sehingga model penelitian yang dipergunakan untuk meneliti e-Filing tidak dapat digunakan pada e-Faktur Pajak. perbedaan mendasar antara implementasi e-Faktur Pajak dan e-Filing adalah, aplikasi e-Faktur Pajak secara mandatori diwajibkan bagi seluruh Wajib Pajak 
yang terdaftar sebagai Pengusaha Kena Pajak, sedangkan e-Filing adalah layanan yang diberikan ke Wajib Pajak sebagai salah satu alternatif kemudahan dalam pelaporan pajak

\subsection{Implikasi Kebijakan}

Penelitian ini dilakukan pada awal implementasi e-Faktur yang berlaku secara nasional pada 1 Juli 2016. Aplikasi yang wajib digunakan oleh Pengusaha Kena Pajak adalah aplikasi berbasis desktop. Dari hasil penelitian dapat dilihat bahwa terdapat 95\% faktor lain yang mempengaruhi seorang Wajib Pajak menggunakan aplikasi e-Faktur. Faktor-faktor tersebut perlu diidentifikasikan agar otoritas pajak dapat mengeluarkan kebijakan yang tepat sasaran di masa yang akan datang.

Saat ini otoritas pajak di Indonesia sedang mengembangkan core tax system atau Sistem Inti Administrasi Perpajakan yang akan mengintegrasikan layanan-layanan perpajakan dalam tiga kanal layanan berbasis internet, sambungan telepon, dan tatap muka atau dikenal dengan 3C (click, call, counter) (Safitra, 2019a). Layanan akan didominasi layanan berbasis internet (click) sehingga penting untuk mengidentifikasi faktor lain yang mendorong Wajib Pajak mau menggunakan layanan daring. Penerapan layanan secara mandatori mungkin dapat mendorong Wajib Pajak untuk menggunakan layanan, namun jika persepsi dan keinginan yang ada dalam diri Wajib Pajak tidak menjadi salah satu faktor yang mendorong dalam penggunaan aplikasi akan memperbesar peluang tingkat ketidakpatuhan. Hasil yang menunjukkan bahwa terdapat signifikansi persepsi kegunaan penggunaan dengan perilaku untuk menggunakan memberikan sinyal bahwa otoritas pajak perlu mensosialisasikan manfaat dari setiap layanan daring yang dikeluarkan.

\section{KESIMPULAN DAN SARAN}

Penelitian ini menunjukkan bahwa persepsi kegunaan penggunaan layanan mempengaruhi perilaku menggunakan aplikasi e-Faktur Pajak sehingga faktor ini dapat dijadikan salah satu sasaran otoritas pajak untuk meningkatkan dorongan penggunaan aplikasi. Pentingnya penentuan sasaran dalam upaya peningkatan kepatuhan pajak menjadi penting, mengingat tingkat kepatuhan formal di Indonesia masih belum optimal sehingga diduga mempengaruhi tingkat realisasi pajak. Namun, faktor-faktor yang ada pada TPB dan TAM belum cukup mewakili faktor yang mempengaruhi dorongan PKP untuk menggunakan aplikasi e-Faktur Pajak, sehingga dapat menjadi pertimbangan penelitian selanjutnya untuk menggunakan pendekatan teori lainnya.

Penelitian ini dilakukan pada awal implementasi aplikasi e-Faktur Pajak. Saat itu kanal layanan hanya berupa aplikasi desktop. Saat ini eFaktur Pajak memiliki tiga kanal, aplikasi desktop, web base, dan host to host. Perpindahan kanal dari desktop ke kanal lainnya merupakan pilihan dari Wajib Pajak didasarkan kemampuan teknologi yang mereka miliki. Gap ini dapat digunakan sebagai penelitian di masa yang akan datang. Selain itu, penelitian ini menggunakan sampel data di Kantor Pelayanan Pajak Pratama Pesanggarahan yang didominasi Pengusaha Kena Pajak kecil. Hal ini terjadi karena adanya aturan dari Pemerintah Daerah yang menerapkan zona usaha. Regulasi ini menyebabkan tidak banyak dan tidak beragam jenis usaha Pengusaha Kena Pajak yang ada di Kantor Pelayanan Pajak Pratama Pesanggrahan.

Masih terdapat ruang untuk penelitian di masa yang akan datang dengan mengeksplorasi variabel lain yang mempengaruhi perilaku yang mendorong penggunaan layanan, sehingga dapat diketahui variabel lain yang belum masuk dalam model pada penelitian ini. Selain itu, peneliti selanjutnya dapat dipertimbangkan memperluas lingkup penelitian menjadi PKP di lingkungan Kantor Wilayah atau tingkat Nasional, sehingga hasil penelitian dapat dijadikan dasar penentuan strategi pengembangan layanan di masa depan. Penerimaan atas layanan atau kebijakan merupakan salah satu faktor internal di diri Wajib Pajak yang meningkatkan kepatuhan pajak, dengan teridentifikasinya persepsi atas kegunaan suatu layanan, maka KPP Pratama Jakarta Pesanggrahan dapat menentukan strategi untuk meningkatkan penerimaan atas layanan dengan mempublikasikan atau mensosialisasikan kegunaan suatu layanan baik bagi Wajib Pajak dan/atau masyarakat umum yang menerima outcome terhaap pembayaran pajak.

\section{DAFTAR PUSTAKA (REFERENCES)}

Ajzen, I. (1985). From intentions to actions: A theory of planned behavior Action control (pp. 11-39): Springer.

Ariasih, N. P., Mahyuni, L. P., \& Putra, A. A. M. S. (2021). Menelisik Penerimaan e-faktur versi 3.0 Melalui Pendekatan Technology Acceptance Model. Jurnal Riset Akuntansi \& Perpajakan (JRAP), 8(01), 37-52.

Bagozzi, R. P., \& Yi, Y. (1988). On the evaluation of structural equation models. Journal of the academy of marketing science, 16(1), 7494. 
Bhuasiri, W., Zo, H., Lee, H., \& Ciganek, A. P. (2016). User Acceptance of e-government Services: Examining an e-tax Filing and Payment System in Thailand. Information Technology for Development, 22(4), 672695.

DeLone, W. H., \& McLean, E. R. (2016). Information systems success measurement. Foundations and Trends ${ }^{\circledR}$ in Information Systems, 2(1), 1-116.

Devos, K. (2013). Factors influencing individual taxpayer compliance behaviour: Springer Science \& Business Media.

Erdiansyah, A. V. (2021). Formal Tax Compliance in Indonesia Through Electronic Tax Filing: A Case Study of Micro, Small, and Medium Enterproses. JURNAL PAJAK INDONESIA (Indonesian Tax Journal), 5(1).

Fishbein, M., \& Ajzen, I. (1977). Belief, attitude, intention, and behavior: An introduction to theory and research. Philosophy and Rhetoric, 10(2).

Hair, J. F., Page, M., \& Brunsveld, N. (2019). Essentials of business research methods: Routledge.

Hsu, M.-H., \& Chiu, C.-M. (2004). Predicting electronic service continuance with a decomposed theory of planned behaviour. Behaviour \& Information Technology, 23(5), 359-373.

Hung, S.-Y., Chang, C.-M., \& Yu, T.-J. (2006). Determinants of user acceptance of the eGovernment services: The case of online tax filing and payment system. Government information quarterly, 23(1), 97-122.

Khairrunnisa, U., \& Yunanto, M. (2018). Pengaruh Kualitas Sistem Terhadap Kepuasan Pengguna dan Manfaat Bersih pada Implementasi e-Faktur: Validasi Model Kesuksesan Sistem Informasi Delone dan Mclean. Jurnal Ilmiah Ekonomi Bisnis, 22(3).

Lallmahomed, M. Z., Lallmahomed, N., \& Lallmahomed, G. M. (2017). Factors influencing the adoption of e-Government services in Mauritius. Telematics and Informatics, 34(4), 57-72.

Lestari, W. T., Suharto, E., Wirawan, P. W., \& Kurniawan, K. (2019). Trust and Risk for Measuring OnlineTax Application Acceptance. Paper presented at the 2019 3rd International Conference on Informatics and Computational Sciences (ICICOS).
Lu, C.-T., \& Ting, C.-T. (2013). A study of tax e-filing acceptance model: A structural equation modeling approach. Paper presented at the 2013 IEEE/ACIS 12th International Conference on Computer and Information Science (ICIS).

Maula, F., Rahim, S., \& Lannai, D. (2020). Beberapa Faktor Yang Mempengaruhi Penggunaan DJP Online. CESJ: Center of Economic Students Journal, 3(1), 1-16.

Nabavi, A., Taghavi-Fard, M. T., Hanafizadeh, P., \& Taghva, M. R. (2016). Information technology continuance intention: A systematic literature review. International Journal of E-Business Research (IJEBR), 12(1), 58-95.

Nugroho, R. A., Susilowati, A. D., Ambarwati, O. C., \& Pratiwi, A. (2018). Factors Affecting Users' Acceptance of E-Billing System in Surakarta Tax Office. ComTech: Computer, Mathematics and Engineering Applications, 9(1), 37-42.

Perangin-angin, W. A., Respati, A. D., \& Kusumawati, M. D. (2018). Pengaruh perceived usefulness dan perceived ease of use terhadap attitude toward using efaktur. Jurnal Riset Ekonomi dan Manajemen, 16(2), 307-322.

Pieterson, W., \& Teerling, M. (2008). Citizen behavior in a multi-channel environment. Paper presented at the Proceedings of the 2008 International conference on Digital government research.

Prawati, L. D., \& Britania, H. (2020). THE IMPACT OF INFORMATION TECHNOLOGY ON TAXATION: CORPORATE TAXPAYERS'INTEREST IN USING DJP ONLINE SYSTEM. PalArch's Journal of Archaeology of Egypt/Egyptology, 17(7), 2451-2462.

Rahmat, A. (2020). Pengaruh Pengetahuan e-filling, Sosialisasi Pajak dan Sanksi Perpajakan terhadap Kepatuhan Wajib Pajak dengan Akhlak sebagai Variabel Moderasi (Studi pada KPP Pratama Makassar Selatan). Universitas Islam Negeri Alauddin Makassar.

Safitra, D. A. (2019a). Belajar dari yang lain: Commercial of The Shelf pada Sistem Inti Administrasi Perpajakan di Indonesia Esai Keuangan Negara: Kontribusi Pemikiran untuk Indonesia (pp. 27-40): Diandra Kreatif.

Safitra, D. A. (2019b). IMPLEMENTASI E-TAX INVOICE: SEBUAH STUDI KOMPARATIF. 
JURNAL PAJAK INDONESIA (Indonesian Tax Journal), 2(1), 95-105.

Safitra, D. A., \& Djamaluddin, S. (2020). Apakah aktivitas pengawasan otoritas pajak mempengaruhi tingkat kepatuhan pajak? studi kasus Wajib Pajak PPN di Indonesia. Kajian Ekonomi dan Keuangan, 4(1), 1738.

Susanto, N. A. (2011). Analisis Perilaku WajibPajak Terhadap Penerapan Sistem e-Filing Direktorat Jenderal Pajak. Thesis. Magister Perencanaan danKebijakan Publik Universitas Indonesia. Jakarta.

Tahar, A., Riaydh, H. A., Sofyani, H., \& Purnomo, W. E. (2020). Perceived ease of use, perceived usefulness, perceived security and intention to use e-filing: The role of technology readiness. The Journal of Asian Finance, Economics, and Business, 7(9), 537-547.

Tambun, S., \& Kopong, Y. (2017). The Effect of EFiling on The of Compliance Individual Taxpayer, Moderated By Taxation Socialization. South East Asia Journal of
Contemporary Business, Economics and Law, 13(1), 45-51.

Uyar, A., Nimer, K., Kuzey, C., Shahbaz, M., \& Schneider, F. (2021). Can e-government initiatives alleviate tax evasion? The moderation effect of ICT. Technological Forecasting and Social Change, 166, 120597.

Venkatesh, V., Sykes, T. A., \& Venkatraman, S. (2014). Understanding e-Government portal use in rural India: role of demographic and personality characteristics. Information systems journal, 24(3), 249-269.

Wiyono, A. S. (2008). Evaluasi Perilaku Penerimaan Wajib Pajak Terhadap Penggunaan E-filing sebagai sarana pelaporan pajak secara online dan realtime. The Indonesian Journal of Accounting Research, 11(2).

Yusup, M., Hardiyana, A., \& Sidharta, I. (2015). User acceptance model on e-billing adoption: $A$ study of tax payment by government agencies. Asia Pacific Journal of Multidisciplinary Research, 3(4), 150-157.

\section{LAMPIRAN I Convergency Validity}




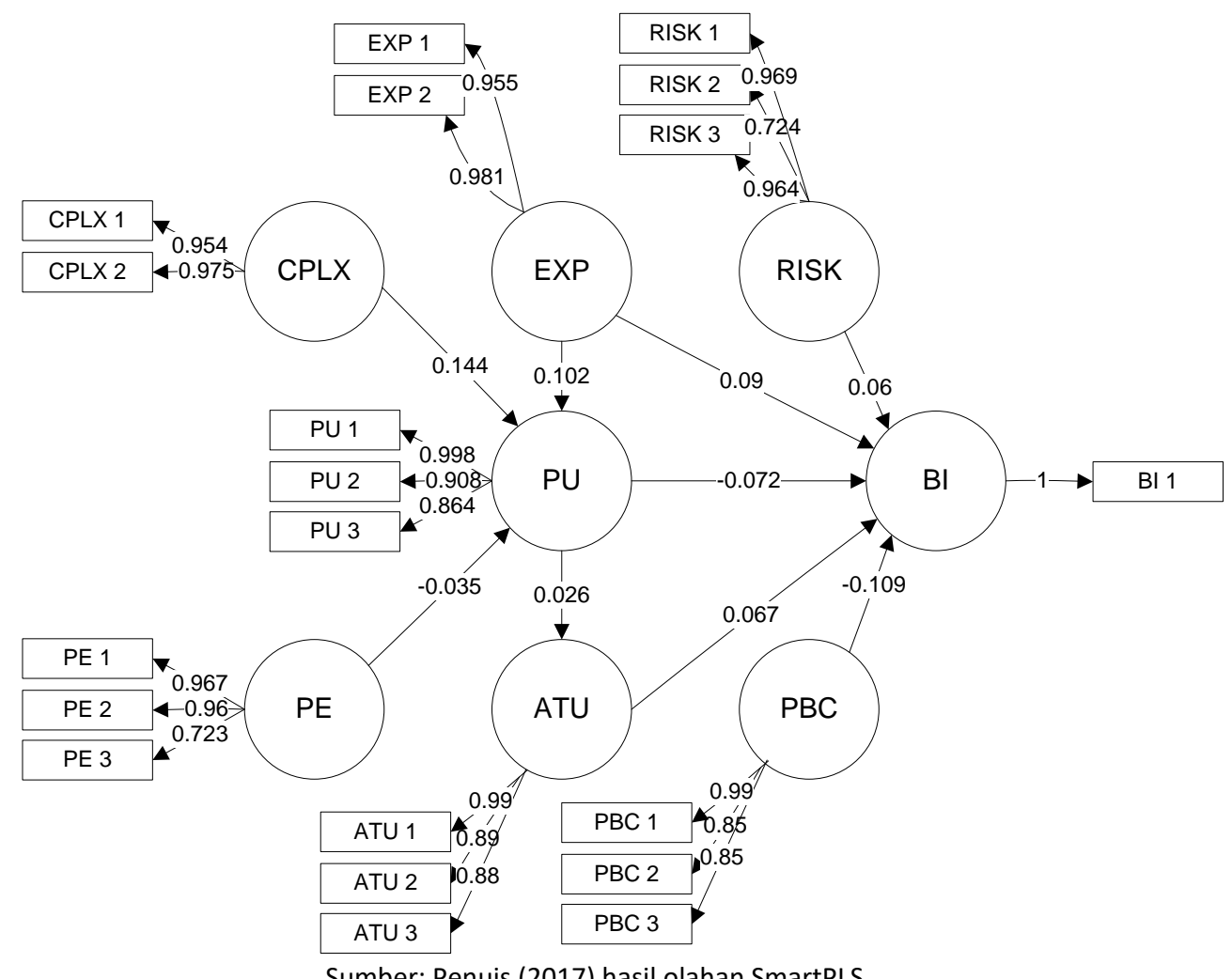

Sumber: Penuis (2017) hasil olahan SmartPLS 


\section{RAHASIA}

\section{KUISIONER}

PENERIMAAN WAJIB PAJAK PADA AWAL IMPLEMENTASI E-FAKTUR PAJAK BERBASIS DESKTOP APPLICATION

\begin{tabular}{lll}
\hline \hline & \multicolumn{1}{c}{ KUNJUNGAN I } & KUNJUNGAN II \\
\hline \hline TANGGAL: & & \\
\hline JAM MULAI: & & \\
\hline JAM BERAKHIR: & [ ] Selesai & [ ] Selesai \\
\hline WAWANCARA: & [ ] Tidak Selesai & [ ] Tidak Selesai \\
& Keterangan: & Keterangan:
\end{tabular}

Selamat pagi/siang/malam Bapak/lbu

Perkenalkan nama kami Dhian Adhetiya Safitra.

Saat ini kami sedang melakukan penelitian dengan judul PENERIMAAN WAJIB PAJAK PADA AWAL IMPLEMENTASI E-FAKTUR PAJAK BERBASIS DESKTOP APPLICATION. Ibu/Bapak kami pilih secara khusus dengan mempertimbangkan keterlibatan Bapak/lbu dan/atau perusahaan yang dipimpin Bapak/Ibu pada implementasi e-Faktur Pajak. Sehubungan dengan hal tersebut kami mohon kesediaan Bapak/Ibu untuk dapat berpartisipasi untuk melakukan pengisian kuisioner ini. Pengisian kuisioner ini akan berlangsung sekitar 15 menit dan Bapak/lbu dapat menghentikan partisipasi Bapak/lbu tanpa ada masalah atau tetap melanjutkan pengisian kuisioner melebihi waktu yang ditetapkan.

Informasi yang Bapak/Ibu berikan pada pengisian kuisioner ini hanya digunakan untuk keperluan penelitian yang akan disusun menjadi rekomendasi kebijakan bukan untuk konsumsi masyarakat umum. Jika terdapat informasi personal pada kuisioner ini seperti data pribadi, kami akan menjaga kerahasiaan informasi tersebut.

Atas ketersediaan Bapak/Ibu menjawab pertanyaan, saya ucapkan terima kasih.

\section{IDENTITAS RESPONDEN}

$\begin{array}{ll}\text { IR01 } & {[\text { ] Badan }} \\ & \text { [ ] Orang Pribadi } \\ \text { IR02 } & \text { Bidang Usaha: } \\ & {[\text { ] ] Perdagangan }} \\ & {[\text { ] Jasa Kontruksi }} \\ & {[\text { ] Jasa Konsultasi }} \\ & {[\text { ] Lainnya ................. }}\end{array}$


IR03 Jabatan

[ ] Pemilik Usaha

[ ] Staff

[ ] Konsultan

[ ] Lainnya.

IR04A Mengoperasikan Aplikasi e-Faktur Pajak?

[ ] Tidak

[ ] Ya selama [ ] [ ] Tahun [ ][ ] Bulan

IR04B Aplikasi e-Faktur yang digunakan

[ $\sqrt{ }$ ] Desktop

[ ] Web Base

[ ] Host to Host

[ ] Host to Host - ASP (Application

IR05 Instansi/Perusahaan Responden:

$\begin{array}{ll}\text { IR06 Media Komunikasi: } & \\ \text { Telepon [Rumah/kantor] } & : \\ \text { Mobile Phone } & : \\ \text { Email } & : \\ \text { Alamat Kantor } & :\end{array}$

Alamat Rumah 


\section{DAFTAR PERTANYAAN}

Lingkari angka pada kotak [ 1 ] 2] [ 3 ] [ [ ] [ 5 ]

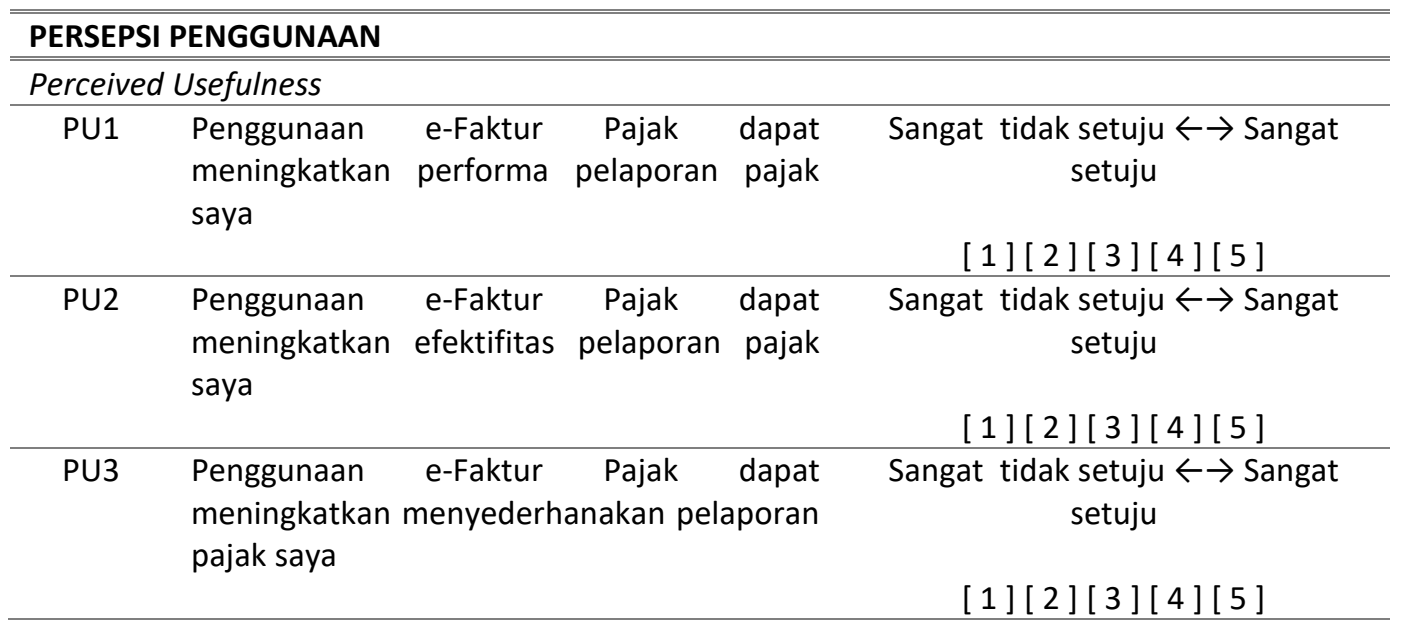

\section{PERSEPSI KEMUDAHAN PENGGUNAAN}

Perceived Easy of Use

PE1 Mudah bagi saya untuk mempelajari aplikasi Sangat tidak setuju $\leftrightarrow \rightarrow$ Sangat e-Faktur Pajak setuju

[1] [ 2 ] [3 ] [ 4 ] [5]

PE2 Manual, katalog error, dan fungsi bantu Sangat tidak setuju $\leftarrow \rightarrow$ Sangat aplikasi e-Faktur Pajak sangat mudah setuju dipahami dan jelas

[1] [ 2 ] [3 ] [ 4 ] [5]

PE3 Secara umum aplikasi e-Faktur Pajak sangat Sangat tidak setuju $\leftrightarrow \rightarrow$ Sangat user friendly atau mudah digunakan setuju

[1][2][3][4][5]

\section{SIKAP TERHADAP PENGGUNAAN}

Attitude Toward Using

ATU1 Saya merasa nyaman menggunakan aplikasi $\quad$ Sangat tidak setuju $\leftarrow \rightarrow$ Sangat e-Faktur

setuju

[1] [ 2 ] [3 ] [ 4 ] [5]

ATU2 Saya menikmati mengoperasikan aplikasi e- $\quad$ Sangat tidak setuju $\leftarrow \rightarrow$ Sangat Faktur setuju

[1][2][3][ 4 ] [5]

ATU3 Saya mearasa frustasi saat menggunakan Sangat tidak setuju $\leftarrow \rightarrow$ Sangat aplikasi e-Faktur setuju

[1][2][3 ] [4 ][5 ] 


\section{MINAT PERILAKU UNTUK MENGGUNAKAN}

Behafioral Intention of Use

BI1 Saya mengharapkan penggunaan aplikasi e- $\quad$ Sangat tidak setuju $\leftarrow \rightarrow$ Sangat

Faktu terus berlanjut di masa datang

setuju

\section{[1][2][3][4][5]}

\section{PENGALAMAN MENGOPERASIKAN APLIKASI E-FAKTUR}

Experience

EXP1 Saya memiliki banyak pengalaman dalam Sangat tidak setuju $\leftarrow \rightarrow$ Sangat mengatasi error pada aplikasi e-Faktur setuju

$$
\text { [1] [ 2 ] [3 ] [ 4 ] [ 5 ] }
$$

EXP2 Saya memiliki pengalaman yang cukup dalam Sangat tidak setuju $\leftarrow \rightarrow$ Sangat mengoperasikan semua menu pada aplikasi setuju e-Faktur

$$
\text { [1][2 ] [3] [4][5] }
$$

\section{PERSEPSI KERUMITAN PENGGUNAAN}

Complexity

CMPX1 Menggunakan aplikasi e-Faktur sangat menyita waktu karena banyak fungsi dan

Sangat tidak setuju $\leftarrow \rightarrow$ Sangat prosedur yang harus dijalankan setuju

$$
\text { [1][2 [ [3 ] [ 4 ] [5] }
$$

CMPX2 Tidak mudah mengintegrasikan Output e- $\quad$ Sangat tidak setuju $\leftarrow \rightarrow$ Sangat Faktur dengan pekerjaan lain setuju

\section{[1][2 ] [3 ] [ 4 ] [5]}

\section{PERSEPSI RISIKO}

Perceived Risk

RISK1 Penggunaan aplikasi e-Faktur menyebabkan informasi faktur pajak perusahaan saya

Sangat tidak setuju $\leftarrow \rightarrow$ Sangat disalahgunakan

setuju

$$
\text { [1][2][3][4][5] }
$$

RISK2 Saya tidak yakin saat menggunakan aplikasi e-Faktur
Sangat tidak setuju $\leftarrow \rightarrow$ Sangat setuju

$$
\text { [1][2][3][4][5] }
$$

RISK3 Menurut saya penggunaan aplikasi e-Faktur tidak aman karena masalah keamanan dan privasi
Sangat tidak setuju $\leftarrow \rightarrow$ Sangat

setuju

[1][2 ][ 3 ] [ 4 ] [5] 


\section{PERSEPSI KEMAMPUAN MENGONTROL}

Percieved Believe Control

PBC1 Saya kesulitan untuk menemukan komputer dan alat pendukung lain yang cocok untuk aplikasi e-Faktur

Sangat tidak setuju $\leftarrow \rightarrow$ Sangat setuju

\section{[1][2][3 ] [ 4 ] [5]}

PBC2 Mudah bagi saya mendapatkan bantuan saat Sangat tidak setuju $\leftarrow \rightarrow$ Sangat kesulitan mengoperasikan aplikasi e-Faktur setuju

\section{[1][2][3][4][5]}

PBC3 Saya mampu menggunakan aplikasi e-Faktur secara mandiri
Sangat tidak setuju $\leftarrow \rightarrow$ Sangat

setuju

[1][2][3 ] [ 4 ] [5] 